\section{Le déficit en une "protéine protectrice » provoque l'inactivité de deux enzymes lysosomiales différentes}

Les nouvelles

de ce numéro

ont été préparées par

Jean-Claude Dreyfus

Serge Erlinger

Axel Kahn

Marc Peschanski
Les déficits en enzymes lysosomiales sont le plus souvent dus à une anomalie individuelle de l'une des multiples enzymes qui peuplent les lysosomes. Il existe cependant des maladies où plusieurs enzymes génétiquement indépendantes sont atteintes en même temps. Ces affections relèvent de deux mécanismes différents : le premier, caractéristique des mucolipidoses II et III, consiste en l'absence du marqueur mannose-6-phosphate, responsable du code postal des enzymes destinées au lysosome $\left(\mathrm{m} / \mathrm{s} n^{\circ} 8\right.$, vol. 3, p. 453); il en résulte un déficit de l'ensemble de ces enzymes. Le second est du à l'absence d'une protéine indispensable à la stabilisation de certaines enzymes; on en connaît deux exemples, le déficit généralisé en arylsulfatases et la galactosialidose.

C'est cette dernière affection qui a été caractérisée le plus en détail ; le déficit porte sur deux enzymes très différentes, la $\beta$-galactosidase et la neuraminidase. Il en existe des formes précoces, qui conduisent à la mort au cours de la première année, et des formes plus tardives marquées par un retard du développement et des anomalies morphologiques. Les deux enzymes sont synthétisées normalement, mais sont rapidement dégradées. La $\beta$-galactosidase, la mieux étudiée, ne peut subir la polymérisation de ses sous-unités, indispensable à la fois à son activité et à sa stabilité. Les deux enzymes sont normalement liées à une «protéine protectrice », un hétérodimère formé de deux sous-unités de 32 et $20 \mathrm{kDa}$ (kilodalton), et qui est absente ou inactive dans la maladie. Si à une culture de fibroblastes d'un malade on ajoute la protéine protectrice, le taux de $\beta$-galactosidase et de neuraminidase revient à la normale.

Le groupe néerlandais responsable de la majorité des travaux sur la galactosialidase vient [1] d'obtenir un ADNc codant pour la protéine humaine; les fibroblastes normaux contiennent un ARN messager de $2 \mathrm{~kb}$ (kilobases); celui-ci s'est montré presque totalement absent des fibroblastes d'un malade atteint de la forme infantile précoce et présent en quantité normale dans ceux d'une forme tardive, qui possèdent également une protéine immunoréactive. Ce messager code pour un précurseur de la protéine, formé d'une chaîne de 458 acides aminés (plus un peptide signal de 28 acides aminés). Un clivage après la position 298 (une arginine) aboutit à la séparation des deux chaînes 32 et $20 \mathrm{kDa}$ qui restent unies entre elles par des liaisons disulfure à la manière de celles de l'insuline. Le caractère le plus curieux de la séquence est une homologie avec deux protéines de la levure qui ont des activités de carboxypeptidase; on est ainsi conduit à attribuer des propriétés protéolytiques, au moins potentielles, à une protéine dont la fonction in vivo semble être de protéger deux enzymes contre leur dégradation.

J.-C. D.

1. Galiart NJ, Gillemans N, Harris A, et al. Expression of cDNA encoding the human "protective protein » associated with lysosomal $\beta$-galactosidase and neuraminidase : homology to yeast proteinases. Cell $1988 ; 54: 755-64$.

\title{
-
}

